\title{
Risk factors relating to helminth infections in cows during the peripartum
}

\author{
Fatores de risco relacionados à infecção por helmintos em vacas durante o periparto \\ Jenevaldo Barbosa da Silva ${ }^{1 *}$; Charles Passos Rangel ${ }^{2}$; \\ Bruna de Azevedo Baêtaª; Adivaldo Henrique da Fonseca²
}

${ }^{1}$ Faculdade de Ciências Agrárias e Veterinárias, Universidade Estadual Paulista - UNESP, Jaboticabal, SP, Brasil

${ }^{2}$ Universidade Federal Rural do Rio de Janeiro - UFRRJ, Seropédica, RJ, Brasil

Received April 25, 2011

Accepted March 3, 2012

\begin{abstract}
The aim of this study was to investigate whether season, lactation number, breed standard and milk production were risk factors relating to occurrences of gastrointestinal nematodes in dairy cows during the peripartum period. Eighty-four cows were randomly selected through proportional stratified sampling. In order to analyze the fecal egg per gram (EPG) count, the data were subjected to the Spearman test, Kruskal-Wallis test at $5 \%$ significance and linear regression. At the time of calving, the cows showed high EPG counts in relation to all variables analyzed. Among the animals studied, we observed that purebred Holstein cows at their first lactation and with high milk production showed high EPG counts (600) and comprised the group most at risk within the herd studied. In this group, the animals showed moderate EPG during the prepartum period (300) and a significant increase $(p<0.01)$ in EPG count from the time of calving (900), i.e. an increase of the order of $300 \%$. Selection of animals for milk production in tropical countries should be based not only on productive potential, but also on adaptive features.
\end{abstract}

Keywords: Season, lactation number, breed standard, milk production.

\section{Resumo}

O objetivo foi investigar a estação do ano, número de lactaçôes, padrão racial e produção de leite como fatores de risco relacionados à ocorrência de helmintos gastrintestinais em vacas durante o periparto. Foram selecionadas randomicamente 84 vacas através de amostragem estratificada proporcional. Para análise dos resultados da contagem de ovos por grama de fezes (OPG), foram utilizados os testes de Spearman, Kruskal-Wallis a 5\% de significância e regressão linear. Entre os fatores de risco avaliados, o parto esteve associado à elevada contagem de OPG em todos os grupos estudados. Por ocasião do parto, as vacas apresentaram alta contagem de OPG em relaçáo a todas as variáveis analisadas. Dentre os animais estudados, observou-se que vacas holandesas puras de primeira lactação e de alta produção leiteira apresentaram elevada contagem de OPG (600), constituindo o grupo de maior risco dentro do rebanho estudado. Nesse grupo, observou-se que os animais apresentaram contagem de OPG moderada no pré-parto (300), com aumento significativo ( $\mathrm{p}<0.01)$ na contagem de OPG a partir do parto $(900)$, na ordem de $300 \%$. A seleçáo de animais para produção de leite, nos países tropicais, deve ser baseada não somente no potencial produtivo, mas também nas características adaptativas.

Palavras-chave: Estação do ano, número de lactação, padrão racial, produção leiteira.

\section{Introduction}

Gastrointestinal nematodes are considered to be the biggest health problem of cattle raised on pasture. They have an important impact on the profitability of dairy production systems (BEASLEY et al., 2010). In addition to this, parasitism

\footnotetext{
*Corresponding author: Jenevaldo Barbosa da Silva

Laboratório de Doenças Parasitárias, Departamento de Parasitologia Animal, Instituto de Veterinária, Universidade Federal Rural do Rio de Janeiro - UFRRJ, BR 465, Km 07, CEP 23890-000, Seropédica, RJ, Brasil

e-mail: jenevaldo@hotmail.com
}

by nematodes may cause changes to the nutritional characteristics of milk, such as decreases in fat content, protein and lactose (RINALDI et al., 2007).

Gastrointestinal helminths in Brazil are mainly controlled through prophylactic use of anthelmintics (CRUZ et al., 2010). Although these drugs have high efficacy, uncontrolled use has resulted in numerous residues in the environment and in occurrences of parasite resistance (KRECEK; WALLER, 2006). Identification of animals with greater vulnerability and the management phase 
in which parasitism becomes more intense can minimize the effects of parasites in herds. This would consequently reduce the indiscriminate use of chemotherapeutics.

In herds, cows in the peripartum period are held responsible as the main source of pasture contamination and subsequent infection of susceptible animals (SILVA et al., 2011). Studies have shown that during late pregnancy and early lactation, systemic antibody levels and the cellular immune response become reduced (HUNTLEY et al., 2004). Some factors have been identified as modulators of the immune response during the peripartum period, like protein metabolism (HOUDIJK et al., 2000; DONALDSON et al., 2001), host genetics and hormones such as prolactin (LIMA; GUIMARÁES, 1992). Because of the importance of this phenomenon, it is also important to know the factors that may be involved in the pathogenesis of peripartum diseases.

Phylogenetic analysis has shown that the differences between taurine and zebuine cattle already existed 610,000 to 850,000 years ago (MIRKEN et al., 2010). It is possible that the genetic diversity from each subspecies significantly influences their adaptation to the parasite (HANOTTE et al., 2003). In goats, in addition to genetic susceptibility, infections caused by nematodes are associated with production capacity (STEAR et al., 2006) and the number of lactations (MANFREDI et al., 2010). Thus, the effects of nematode infection depend on the host species involved, breed, age of the animal, physiological condition and parasite intensity (HOSTE et al., 2005).

Knowledge about risk factors for helminthiasis is essential for guided use of anthelmintics, however, there are few studies on dairy cows in tropical areas. Such studies may point towards logical ways of using selective treatment among dairy cows in order to reduce the production costs and problems caused by resistance to anthelmintics (VERCRUYSSE, 2009). Thus, the aim of the present study was to investigate whether the variables of season of the year, lactation number, breed and milk production were risk factors relating to occurrences of gastrointestinal nematodes in dairy cows during the peripartum period, in a tropical region.

\section{Material and Methods}

Field activities were conducted from September 2008 to August 2009, at the Dairy Cattle Division of Seropédica Experimental Station, Agricultural Research Corporation of the State of Rio de Janeiro (Rio-Pesagro). The experimental area was located in the microregion of the Metropolitan Region of Rio de Janeiro (latitude $22^{\circ} 45^{\prime} \mathrm{S}$ and longitude $43^{\circ} 41^{\prime} \mathrm{W}$ and altitude $33 \mathrm{~m}$ ).

By means of proportional stratified sampling, 84 cows were randomly selected: 44 of them had calved in the rainy season and 40 in the dry season. Among the animals studied, 26 were at their first lactation, 29 at the second and 29 at the third or subsequent lactation. The breed standard was as follows: 20 were pure Holstein crossbred; 28 were of crossbred blood ( $1 / 2$ Holstein $\times 1 / 2$ Gir); 21 were Girolando (5/8 Gir × 3/8 Holstein); and 15 were pure Gir by crossbreeding. In order to evaluate the milk production, the cows were grouped according to their annual productivity. There were 27 cows that were producing less than $1500 \mathrm{~kg}$ of milk, 37 that were producing between 1500 and $3000 \mathrm{~kg}$ of milk and 20 that were producing more than $3000 \mathrm{~kg}$ of milk.

In accordance with the management method used at the Experimental Station, the pregnant cows were kept on an area of Brachiaria decumbens grass at an animal density of five cows per hectare for the 30 days prior to calving. After calving and during the first four weeks of lactation, the animals were kept on pasture consisting of $B$. decumbens and Panicum maximum at a density of three animals per hectare. In both areas, the animals received water and mineral salt ad libitum. During the lactation period, the cows were milked twice a day. The cows received $3 \mathrm{~kg}$ of commercial concentrate per day, consisting of citrus pulp and commercial animal feed containing $22 \%$ crude protein, in a 2:1 ratio.

Feces from the cows were sampled three times a week: during the four weeks of the prepartum period, in the week of calving and in the four weeks of the postpartum period. The fecal parasitological analyses were performed at the Parasitic Diseases Laboratory, Department of Epidemiology and Public Health, Institute of Veterinary Medicine of the Federal Rural University of Rio de Janeiro. The egg per gram (EPG) count of gastrointestinal nematodes in the feces was accomplished through the technique described by Ueno and Gonçalves (1998).

To investigate the influence of the variables of season of the year, lactation number, breed standard and milk production as risk factors for occurrences of gastrointestinal nematodes in dairy cows, the average EPG counts observed in prepartum, calving and postpartum periods were firstly subjected to the Spearman test to ascertain whether any association existed between them, and comparisons were then made using the nonparametric Kruskal-Wallis test at $5 \%$ significance and linear regression. The operational procedures were done with the aid of the statistical software R Foundation for Statistical Computing, version 2.12.2 (2011).

\section{Results}

The EPG counts in feces from the cows and the linear regression during the four weeks of the prepartum period, calving period (fifth week) and the four weeks of the postpartum period are shown in Figure 1. Analysis on the results within groups showed that the mean EPG count at parturition was significantly higher $(\mathrm{p}<0.05)$ than in the prepartum and postpartum periods. On the other hand, comparison of EPG counts between the prepartum and postpartum periods showed that they were significantly lower during the prepartum period $(\mathrm{p}<0.05)$ only among animals that had been raised using the conventional system.

The mean values and standard deviations of the egg counts of gastrointestinal helminths from peripartum cows during the rainy and dry seasons are shown in Table 1. The mean EPG counts were highly correlated $(0.70)$ with the nine peripartum weeks, such that egg elimination during calving and the postpartum period was significantly higher $(\mathrm{p}<0.05)$ than during the prepartum period, in both seasons. In the rainy season, egg elimination during calving was significantly higher than during the postpartum period. However, this difference was not observed during the 


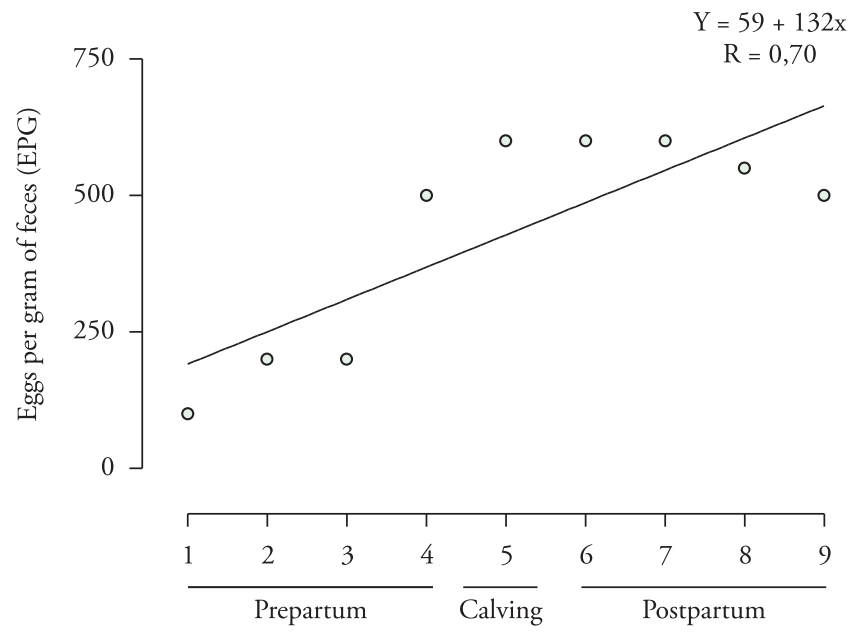

Figure 1. Egg counts in feces from cows and the linear regression, during the four weeks of the prepartum period, parturition (fifth week) and the four weeks of the postpartum period, at Pesagro-Rio from 2008 to 2009 .

Table 1. Egg counts in feces from cows during the prepartum, calving and postpartum periods, in the rainy and dry seasons, at Pesagro-Rio from 2008 to 2009.

\begin{tabular}{cccc}
\hline Season & Prepartum & Calving & Postpartum \\
\hline Rain & $210 \pm 210^{\mathrm{Ac}}$ & $605 \pm 240^{\mathrm{Aa}}$ & $500 \pm 189^{\mathrm{Ab}}$ \\
Dry & $285 \pm 80^{\mathrm{Ab}}$ & $590 \pm 203^{\mathrm{Aa}}$ & $550 \pm 60^{\mathrm{Aa}}$ \\
\hline
\end{tabular}

Average followed by capital letters in the same column and lower case differ among themselves by nonparametric Kruskal-Wallis test at 5\% of probability respectively.

dry season. There was no statistical difference $(p>0.05)$ in EPG counts between the animals that gave birth during one season and the other.

The EPG counts in the feces from cows at their first, second and third or subsequent lactation, during the peripartum period, are shown in Table 2. Egg elimination in feces varied significantly $(p<0.05)$, depending on the number of lactations. Throughout the peripartum period, animals at their first lactation showed higher EPG counts than shown by animals at their second and third or subsequent lactation.

In the breed groups studied, cows with a higher degree of Holstein blood showed higher egg elimination, with significant differences for purebred Holsteins at all phases of the peripartum period (Table 3 ). Holstein and half-blood animals $(1 / 2$ Holstein $\times 1 / 2$ Gir $)$ showed a significant decrease in EPG count during the postpartum period, while the other breeds maintained egg elimination levels similar to those during calving.

Animals producing more than $3000 \mathrm{~kg}$ of milk per year showed significantly higher egg elimination $(p<0.01)$ than shown by animals with lower milk production (Table 4). In all three study groups, egg elimination in the feces increased after calving $(\mathrm{p}<0.05)$.

Among the animals studied, we observed that the purebred Holstein cows at their first lactation and with high milk production $(n=8)$ showed high egg counts (600 EPG), thus composing the group that was most at risk within the herd studied. In this
Table 2. Egg counts in feces from cows at the first, second and third or subsequent lactation, during the prepartum, calving and postpartum periods, at Pesagro-Rio from 2008 to 2009.

\begin{tabular}{cccc}
\hline $\begin{array}{c}\text { Lactation } \\
\text { number }\end{array}$ & Prepartum & Calving & Postpartum \\
\hline $1^{\text {st }}$ Lactation & $320 \pm 110^{\mathrm{Ac}}$ & $769 \pm 242^{\mathrm{Aa}}$ & $520 \pm 104^{\mathrm{Ab}}$ \\
$2^{\text {nd }}$ Lactation & $120 \pm 92^{\mathrm{Bc}}$ & $540 \pm 235^{\mathrm{Ba}}$ & $285 \pm 137^{\mathrm{Bb}}$ \\
$3^{\text {rd }}$ Lactation & $105 \pm 140^{\mathrm{Bb}}$ & $424 \pm 128^{\mathrm{Ba}}$ & $358 \pm 112^{\mathrm{Ba}}$ \\
\hline
\end{tabular}

Average followed by capital letters in the same column and lower case differ among themselves by nonparametric Kruskal-Wallis test at $5 \%$ of probability respectively.

Table 3. Fecal egg counts from Holstein, $1 / 2$ Holstein $x 1 / 2$ Gir, Girolando and Gir cows during the prepartum, calving and postpartum periods, at Pesagro-Rio from 2008-2009.

\begin{tabular}{cccc}
\hline Degree of blood & Prepartum & Calving & Postpartum \\
\hline Holstein & $230 \pm 123^{\mathrm{Ac}}$ & $812 \pm 280^{\mathrm{Aa}}$ & $431 \pm 171^{\mathrm{Ab}}$ \\
${ }^{1 / 2}$ Holstein x ${ }^{1 / 2}$ Gir & $115 \pm 119^{\mathrm{Bc}}$ & $515 \pm 211^{\mathrm{Ba}}$ & $232 \pm 153^{\mathrm{Bb}}$ \\
Girolando & $109 \pm 120^{\mathrm{Bc}}$ & $408 \pm 206^{\mathrm{Ca}}$ & $300 \pm 139^{\mathrm{Ba}}$ \\
Gir & $84 \pm 94^{\mathrm{Bb}}$ & $290 \pm 105^{\mathrm{Ca}}$ & $270 \pm 65^{\mathrm{Ba}}$ \\
\hline
\end{tabular}

Average followed by capital letters in the same column and lower case differ among themselves by nonparametric Kruskal-Wallis test at $5 \%$ of probability respectively.

Table 4. Egg counts in feces from cows with annual milk production of less than 1500, between 1500 and 3000 and greater than $3000 \mathrm{~kg} / \mathrm{cow} /$ year, during the prepartum, calving and postpartum periods, at Pesagro-Rio from 2008 to 2009.

\begin{tabular}{cccc}
\hline $\begin{array}{c}\text { Milk } \\
\text { production } \\
\text { cow/year }\end{array}$ & Prepartum & Calving & Postpartum \\
\hline$<1500$ & $190 \pm 92^{\mathrm{Bb}}$ & $420 \pm 187^{\mathrm{Ba}}$ & $380 \pm 82^{\mathrm{Ba}}$ \\
$>1500 \mathrm{a}<3000$ & $240 \pm 104^{\mathrm{Bb}}$ & $510 \pm 121^{\mathrm{Ba}}$ & $359 \pm 123^{\mathrm{Ba}}$ \\
$>3000$ & $656 \pm 289^{\mathrm{Ab}}$ & $982 \pm 308^{\mathrm{Aa}}$ & $1090 \pm 254^{\mathrm{Aa}}$ \\
\hline
\end{tabular}

Average followed by capital letters in the same column and lower case differ among themselves by nonparametric Kruskal-Wallis test at 5\% of probability respectively.

group, it was observed that the animals showed moderate egg counts during the prepartum period (300 EPG) and a significant increase $(p<0.01)$ in egg counts during calving (to $900 \mathrm{EPG}$ ), i.e. an increase of the order of $300 \%$ in EPG count.

The results from fecal parasitological cultures demonstrated that Haemonchus was predominant (70\%), followed by Trichostrongylus (22\%), Cooperia (6\%) and Oesophagostomum (2\%). There was no significant difference $(\mathrm{p}<0.05)$ in helminth populations between the risks groups evaluated.

\section{Discussion}

The increase in egg elimination during the peripartum weeks highlights the importance of the phenomenon of immunity relaxation on the size of the gastrointestinal helminth population (CONNAN, 1968). Likewise, Borgsteede (1978) observed that dairy cows (Holstein $\times$ zebuine) showed a significant increase in 
EPG counts at calving and during the subsequent period due to low resistance during calving and lactation. Gennari et al. (2002) observed an increase in EPG counts due to calving among Holstein cows, but the average EPG counts were lower than those found in the present study. Increased EPG counts were also observed by Viana et al. (2009) among beef cows at the time of calving. In a study on the seasonal fluctuation of gastrointestinal nematodes in sheep, Taylor (1935) observed that the peripartum phenomenon contributed significantly towards increased EPG counts, thus overcoming the risk factor of season.

The maintained EPG counts during calving and postpartum that were presented only in the dry season can be explained by the declining availability of forage and lower protein intake. Donaldson et al. (2001) observed that at the late pregnancy and early lactation stages, cows presented high protein demand.

According to Ueno and Gonçalves (1998), the average EPG count during calving among cows at their first lactation could be classified as heavy infection. The finding that the animals presented higher EPG counts at their first lactation corroborates the results of Gennari et al. (2002), who found greater resistance in cows subjected to successive infections, with consequent decreases in EPG counts. Viana et al. (2009) did not observe any difference in average EPG counts when comparing beef cows with one or two lactations and beef cows with three or more lactations.

Breed is an important tool for controlling nematodes in a sustainable production system, when use of anthelmintics is not allowed (BAKER, 1995). In the present study, the pure Holstein crossbred cows showed heavy infection in the week of calving (UENO; GONÇALVES, 1998). Studies conducted in sub-Saharan Africa have shown that zebuine animals are more resistant than European animals (BAKER et al., 1998). Use of crossbred zebuine animals combined with nutritional supplementation and pasture management has been shown to have a positive impact on helminth control (KARUGIA et al., 2000). Philipsson (2000) stated that in tropical and subtropical countries, indiscriminate crossing between native breeds and Holstein animals, thereby generating animals with more than $75 \%$ Holstein blood, has created crossbred animals that are highly susceptible to diseases. Among sheep, genetics strongly influences immunity relaxation during calving, and can be used as a tool for selection of resistant animals. However, this characteristic only presents moderate heritability (LIMA; GUIMARÂES, 1992).

Saueressing and Biachin (1997) observed the influence of egg production by gastrointestinal nematodes during the peripartum period among crossbred and Zebu cows and reported an increasing trend during calving and over the following six weeks. A similar tendency was observed in a study on Girolando and Gir animals, which maintained the same egg elimination levels during the postpartum period that had been presented when calving.

The EPG averages during the calving and postpartum periods among the cows with annual productivity of more than $3000 \mathrm{~kg}$ were classified as heavy infection (UENO; GONÇALVES, 1998). In a review by Coop and Kyriazakis (1999), it was stated that the ruminants' response depends on their production level, nutritional status and metabolic requirements for milk production. Early in the lactation period, particularly at the time of negative energy balance, there is a decrease in resistance (PRYCE et al., 2000). During this period, the energy required to maintain an active immune system is diverted to milk production, thus leading to reduced ability to fight parasites (COLLARD et al., 2000). According to Van Der Waaij (2004), the animal's physiological priority is milk production, so the higher the energy demand of the production system is, the lower the availability of nutrients will be to keep the immune system active. Hoste et al. (2002) evaluated egg elimination among goats of different milk production levels and found that productivity had a positive correlation with the parasitism rate. Studies in Brazil (LIMA; GUIMARÁES, 1992; LIMA, 1998) have reported that the increased EPG counts in cows that have recently calved and during early lactation are important as a major sources of pasture contamination and subsequent contamination of the calves, which in turn may cause subclinical disease in cows.

When analyzing the results separately, we observed that the lactation number, milk production and breed were important risk factors for occurrences of clinical helminthiasis. These results were corroborated by the multivariate analysis, which showed that pure Holstein cows at their first lactation and with high milk production were the group that was most at risk within the herd studied. However, further studies are needed with a larger number of animals and assessment of other risk factors, in order to confirm the real importance of each variable.

The predominance of Haemonchus is worrisome given that this parasite can cause severe anemia and hypoproteinemia, depression, loss of body condition, reduced productivity and possibly death (AMARANTE, 2011). Lima (1998) concluded that Haemonchus was singly the most important of all the gastrointestinal nematodes that constrain the survival and productivity of cows owned by the rural poor in the developing world. This hematophagous parasite is infamous throughout the humid tropics and subtropics, and is responsible for acute disease outbreaks with high mortality levels, particularly among young animals (KRECEK; WALLER, 2006)

\section{Conclusions}

Regardless of the season, pure Holstein cows at their first lactation and with annual milk production more than $3000 \mathrm{~kg}$ were most susceptible to infections with gastrointestinal nematodes during the peripartum period. These factors thus constitute an important risk in relation to the epidemiology of these parasites. This finding demonstrates that within a heterogeneous herd, strategic control methods against helminths that take into account the level of risk to which each animal is subjected need to be implemented.

\section{Acknowledgements}

CNPq and FAPERJ for financial support. Pesagro-Rio for providing the animals for the study.

\section{References}

Amarante AFT. Why is it important to correctly identify Haemonchus species? Rev Bras Parasitol Vet 2011; 20(4): 263-268. http://dx.doi. org/10.1590/S1984-29612011000400002

Baker RL, Mwamachi DM, Audho JO, Aduda EO, Thorpe W. Resistance of Galla and Small East African goats in the sub-humid tropics to gastrointestinal nematode infections and the peri-parturient rise in faecal egg counts. Vet Parasitol 1998; 79(1): 53-64. http://dx.doi.org/10.1016/ S0304-4017(98)00151-4 
Baker RL. Genetics of disease resistance in small ruminants in Africa. In: Gray GD, Woolaston RR, Eaton BT. Breeding for resistance to infectious diseases of small ruminants. Canberra: ACIAR Monograph; 1995. p. 120-138.

Beasley AM, Kahn LP, Windon RG. The periparturient relaxation of immunity in Merino ewes infected with Trichostrongylus colubriformis: parasitological and immunological responses. Vet Parasitol 2010; 168(1-2): 60-70. PMid:19775817. http://dx.doi.org/10.1016/j. vetpar.2009.08.028

Borgsteede FHM. Observations on the post-parturient rise of nematode egg-output in cattle. Vet Parasitol 1978; 4(4): 385-391. http://dx.doi. org/10.1016/0304-4017(78)90024-9

Collard BL, Boettcher PJ, Dekkers JC, Petitclerc D, Schaeffer LR. Relationships between energy balance and health traits of dairy cattle in early lactation. J Dairy Sci 2000; 83(11): 2683-2690. http://dx.doi. org/10.3168/jds.S0022-0302(00)75162-9

Connan RM. Studies on the worm populations in the alimentary tract of breeding ewes. J Helminthol 1968; 42(1-2): 9-28. http://dx.doi. org/10.1017/S0022149X00027176

Coop RL, Kyriazakis I. Nutrition-parasite interaction. Vet Parasitol 1999; 84(3-4): 187-204. http://dx.doi.org/10.1016/S0304-4017(99)00070-9

Cruz DG, Rocha LO, Arruda SS, Palieraqui JG, Cordeiro RC, Santos Junior E, et al. Anthelmintic efficacy and management practices in sheep farms from the state of Rio de Janeiro, Brazil. Vet Parasitol 2010; 170(3-4): 340-343. PMid:20356679. http://dx.doi. org/10.1016/j.vetpar.2010.02.030

Donaldson J, Van Houtert MFJ, Sykes AR. The effect of dietary fish-meal supplementation on parasite burdens of periparturient sheep. Anim Sci 2001; 72(1): 149-158.

Gennari SM, Blasques LS, Rodrigues AAR, Cilento MC, Souza SLP, Ferreira F. Determinação da contagem de ovos de nematódeos no período peri-parto em vacas. Braz J Vet Res Anim Sci 2002; 39(1): 32-37.

Hanotte O, Ronin Y, Agaba M, Nilsson P, Gelhaus A, Horstmann R, et al. Mapping of quantitative trait loci controlling trypanotolerance in a cross of tolerant West African N'Dama and susceptible East African Boran cattle. PNAS 2003; 100(13): 7443-7448. PMid:12805560 PMCid:164605. http://dx.doi.org/10.1073/pnas.1232392100

Hoste H, Chartier C, Le Frileux Y. Control of gastrointestinal parasitism with nematodes in dairy goats by treating the host category at risk. Vet Res 2002; 33(5): 531-546. PMid:12387488. http://dx.doi.org/10.1051/ vetres:2002037

Hoste H, Torres-Acosta JF, Paolini V, Aguilar-Caballero A, Etter E, Lefrileux $\mathrm{Y}$, et al. Interactions between nutrition and gastrointestinal infections with parasitic nematodes in goats. Small Rumin Res 2005; 60(1-2): 141-151. http://dx.doi.org/10.1016/j.smallrumres.2005.06.008

Houdijk JG, Kyriazakis I, Jackson F, Huntley JF, Coop RL. Can an increased intake of metabolizable protein affect the periparturient relaxation in immunity against Teladorsagia circumcincta in sheep? Vet Parasitol 2000; 91(1-2): 43-62. http://dx.doi.org/10.1016/ S0304-4017(00)00255-7

Huntley JF, Jackson F, Coop RL, Macaldowie C, Houdijk JG, Familton AS, et al. The sequential analysis of local inflammatory cells during abomasal nematode infection in periparturient sheep. Vet Immunol Immunopathol 2004; 97(3-4): 163-176. PMid:14741135. http://dx.doi. org/10.1016/j.vetimm.2003.09.002

Karugia JT, Mwai OA, Kaitho R, Ducker AG, Wollny CBA, Rege JEO. Economic analysis of crossbreeding programmes in Sub-Saharan Africa: a conceptual framework and kenyan case study [online]. 2000 [cited 2011 Jan. 10]. Available from: http://www.feem.it/userfiles/attach/Publication/ NDL2001/NDL2001-106.pdf.
Krecek RC, Waller PJ. Towards the implementation of the "basket of options" approach to helminth parasite control of livestock: Emphasis on the tropics/subtropics. Vet Parasitol 2006; 139(3): 270-282. PMid:16764993. http://dx.doi.org/10.1016/j.vetpar.2006.04.018

Lima WS. Seasonal infection pattern of gastrointestinal nematodes of beef cattle in Minas Gerais State- Brazil. Vet Parasitol 1998; 74(2-4): 203-214. http://dx.doi.org/10.1016/S0304-4017(97)00164-7

Lima WS, Guimarães MP. Comportamento das infecções helmínticas em vacas de rebanho de corte durante a gestação e lactação. Arq Bras Med Vet Zootec 1992; 44(5): 387-396.

Manfredi MT, Di Cerbo AR, ZanzaniS, Stradiotto K. Breeding management in goat farms of Lombardy, northern Italy: Risk factors connected to gastrointestinal parasites. Small Rumin Res 2010; 88(2-3): 113-118. http://dx.doi.org/10.1016/j.smallrumres.2009.12.018

Mirken T, Dugum G, Haile A, Tibbo M, Okeyo AM, Wurzinger M, et al. Genetics of adaptation in domestic farm animals: A review. Livest Sci 2010; 132(1-3): 1-12. http://dx.doi.org/10.1016/j.livsci.2010.05.003

Philipsson J. Sustainability of dairy cattle breeding systems utilising artificial insemination in less developed countries - examples of problems and prospects. In: Galal S, Boyazoglu J, Hammond K. Developing breeding strategies for lower input animal production environments: an introduction. 3rd ed. Rome: International Committee for Animal Recording - ICAR); 2000. p. 551-562. Technical Serie.

Pryce JE, Coffey MP, Brotherstone S. The genetic relationship between calving interval, body condition score and linear type and management traits in registered Holsteins. J Dairy Sci 2000; 83(11): 2664-2671. http:// dx.doi.org/10.3168/jds.S0022-0302(00)75160-5

Rinaldi L, Veneziano V, Cringoli G. Dairy goat production and the importance of gastrointestinal strongyle parasitism. Trans $R$ Soc Trop Med Hyg 2007; 101(8): 745-746. PMid:17433822. http://dx.doi. org/10.1016/j.trstmh.2007.03.010

Sauressig TM, Bianchin I. Relação entre produção de ovos de nematódeos gastrintestinais e período peri-parto em vaca zebu e mestiças no Distrito Federal. Rev Bras Parasitol Vet 1997; 6(2 Supl 1).

Silva JB, Fagundes GM, Fonseca AH. Dynamics of gastrointestinal parasitoses in goats kept in organic and conventional production systems in Brazil. Small Rumin Res 2011; 98 (1-3):35-38. http://dx.doi. org/10.1016/j.smallrumres.2011.03.014

Stear MJ, Doligalska M, Donskow-Schmelter K. Alternatives to anthelmintics for the control of nematodes in livestock. Parasitol 2006; 134(2): 139-151.

Taylor EL. Seasonal fluctuation in the number of eggs of trichostrongylid worms in the faeces of ewes. J Parasitol 1935; 21(3): 175-179. http:// dx.doi.org/10.2307/3271470

Ueno H, Gonçalves PC. Manual para diagnóstico das helmintoses de ruminantes. 4th ed. Tokyo: Japan International Cooperation Agency; 1998.

Van Der Waaij EH. A resource allocation model describing consequences of artificial selection under metabolic stress. J Anim Sci 2004; 82(4): 973-981. PMid:15080316.

Vercruysse J, Jackson F, Besier B, Pomroy B. Novel solutions for the sustainable control of nematodes in ruminants. Vet Parasitol 2009; 164(1): 1-2. PMid:19447549. http://dx.doi.org/10.1016/j. vetpar.2009.04.025

Viana RB, Bispo JPB, Araújo CV, Benigno RNM, Monteiro BM, Gennari SM. Dinâmica da eliminação de ovos por nematódeos gastrintestinais, durante o periparto de vacas de corte, no Estado do Pará. Rev Bras Parasitol Vet 2009; 18(4): 49-52. http://dx.doi.org/10.4322/rbpv.01804009 